\title{
The Comparative Analysis of Personality and Beliefs About Knowledge Towards Academic Performance at Three Levels Accreditation of Universities in Indonesia : Evidence from Accounting Students in Indonesia
}

\author{
Alfiati Silfi *1 Mohamad Ali Abdul Hamid ${ }^{2}$ \\ 1. Lecturer, Faculty of Economic and Bussiness, University of Riau, \\ Campus Binawidya KM.12,5 Simpang baru, Tampan, Pekanbaru, Riau, Indonesia, 28296 \\ 2. Lecturer, School of Accountancy, Northern University of Malaysia
}

\begin{abstract}
The development of the accountancy profession in Indonesia is not as fast as other Southeast Asian countries.. Accounting graduates should be able to fill in the accountancy profession but a little interested. This problem started out of the process of accounting education especially output of the learning process namely Academic Performance.. The objective of the study is to investigate the comparative influence of personality and beliefs about knowledge on Academic Performance among on accounting student in Indonesia. The participants of this research were 750 Indonesian accounting students at three level accreditation. Data were analyzed with Regression and path analysis to examine the relationship among the variables. The result showed that personality influenced the academic performance at level $\mathrm{B}$ accreditation and beliefs about knowledge influenced the Academic Performance at level A accreditation, and the two of independent influenced the Academic performance at level $\mathrm{C}$ accreditation. Furthermore, accounting students at $\mathrm{C}$ accreditation university has the largest influence of personality towards Academic Performance. In the other hand, accounting students at A accreditation university has the largest influence of beliefs about knowledge towards Academic Performance . These findings will contribute to the literary education of accounting in which psychological factors required for accounting students to get academic performance best in their studies. Next when they, they were more competent, willing and interested to join the accounting profession.
\end{abstract}

Keywords-Academic Performance, Personality factors, Beliefs about knowledge, Regression Analysis, Accounting profession

DOI: $10.7176 / \mathrm{RJFA} / 11-6-13$

Publication date:March $31^{\text {st }} 2020$

\section{Introduction}

1.1 Background of the Study

The development of the world today possessed more advanced elements that require an entire organization looking for opportunities and strategic positioning and competitive advantage. The entire profession, therefore, participated in a variety of the business world. One of the essential components to ensure an organization achieves its goal is to have a human resources expert and skilled in their fields of which accounting profession is no exception.

To generate information about the state of a business that meet the need of various parties made the accounting profession of account increasingly play a significant role.

When compared to some countries in the ASEAN region, the number of public accountants in Indonesia is very far behind. Whereas under the law 40/2007 on limited liability companies, a company that has a turnover of at least 50 billion rupiahs is mandat to appoint or engage public accountants for their audit of financial statements and report. To date, the number of public accountants in Indonesia stands at 1,000 (a nation with a population of 240 million). Whereas, countries with a lower population such as Singapore and Philippines, have more than 20,000 public accountants. Indonesia is currently only able to produce 60 public accountants every year while Singapore and the Philippines graduated 1,000 public accountants annually.

The growth rate of the public accountants in Indonesia is very slow and tends to be stagnant, while the regeneration of accountant is also slow. When compared to the total population, the growth get worse. In addition the distribution of ages of public accountants is very alarming and with the number of accountants is dominated by an already advanced age.

Until early 2014, at least, there were vacancies in several organizationsin Indonesia that require the services of about 226000 public accountants. Meanwhile, the center for the construction of the accountants and appraisers resident in the ministry of finance noted the available labor force is less than 16000 . This means that Indonesia's demand for professional accountants is high and requires urgent attention to meet the need of the Indonesia domestic market should absorb other foreign professional accountants into the domestic business activities with proper monitoring by the government and the IICPA by providing the necessary enabling environment and regulation. With the developing market, Indonesia would be a target for foreign accountants and the quality of 
accounting and auditing task would improve tremendously through knowledge sharing (Anton, 2014). Wellyan (2015) also mentioned that Indonesia still shorthanded with professional accountants. The above facts demonstrate that the needs of accountant in Indonesia is still not able to be filled by the domestic market. So to meet this need, Indonesia should absorb the foreign professionals.

What is the lacking in Indonesian education or learning process that could not generate prospective professional accountant as the like of our neighboring countries such as Malaysia and Singapore? Why is our accounting graduates not greatly interested in filling the accounting profession? Is it because they are not confident with the knowledge that has been acquired in university? How could colleges or universities producing graduates in the field of accounting but do not want to be an accountant? According to Nasir (2012), the current condition of accounting graduates are not ready to work or practice, so that it becomes the responsibility of accounting education to improve their knowledge and competency. Moreover, in the International Education Standard (IES) required an accounting graduates must be competence upon completed their study. However in Indonesia, accounting graduates must continue or further their education to the next stage that is the competency education.

Before entering the accounting profession such as public accountant, accounting graduates should take the certified public accountant (CPA) exam. The test material to be tested is the accounting and financial reporting, business environment, commercial law and taxation, Auditing and Assurance, management accounting, financial management and information systems. The exam participants must pass the exam for the whole exam material. The exam participants who do not pass in its entirety, then, the exams that have passed considered did not pass. For participants who wish to take the exam again, the participant must repeat the entire exam. Thus, it is very difficult to pass from certification public accountant exam (Cahyo, 2011). Therefore accounting graduate who wants to do the CPA exams must have good performance in their study. The performance of their study come from the accounting education process.

This problem we can search in the field of education process, because the education process that the candidates go through should have produce the accountant ready to work in the accounting profession. For that it is a need to examine the factors that lead to field of education especially higher education who do not effectively produce the graduates to have the capability and confidence in the subject matter.

One way to measure the capabilities of the students is through their academic performance (Ciorbea \& Pasarica, 2013; Heiskanen \& Lonka, 2012; Mevlana, 2011). Academic performance of the student could reflect their capability in order to be a professional accountant.

To examine what factors can affect academic performance, O'Connor \& Paunonen (2007); March (2010) advocate at educational psychology. It is due to the factor that derived from human personal psychology that can encourage and motivate people to organize something that is desirable and satisfactory. Likewise with academic performance, the student will be encouraged to increase their academic performance due to psychological factors attached to them such as nature, attitudes, and beliefs that they have from birth until adulthood (March, 2010). However, research in the field of accounting education concerning these factors are still very little (Phillips, 1998; Hassal \& Joice, 2001; Davidson, 2002; Ballantine et al., 2008 and Fisher 2013).

The first factor that can influence academic performance is personality (De Reed \& Schouwenberg, 1996; O’Connor \& Paunonen, 2007; Chamorro-Premuzic \& Furnham, 2008; Mitrofan \& Ion, 2013). Personality is a factor that is concerned with the characteristics of a person and has many dimensions (Mitrofan\&Ion, 2013). An important dimension of personality is called The BIG FIVE personality factors. These are agreeableness, extraversion, conscientiousness, neuroticism and openness to experience (Davidson, 2001; Furnham, et al., 2003; Chamorro-Premuzic \& Furnham, 2003; Philips, 1998;Goldberg, 1993;Komarraju; Karau, Schmeck \& Avdic, 2011; Ciorbea \& Pasarica, 2013; Batterson, Tormey and Ritchiec, 2014).

The second factor that could further affect academic performance is the beliefs about knowledge (Barvarz, Nami \& Ahmadi, 2014;Siegel, 1989; March, 2010). Beliefs about knowledge are a factor in someone's beliefs to the knowledge that is learned. The dimensions of these beliefswere also known by the term "Epistemological Beliefs".Epistemology is one of the main areas of philosophy deals with nature and justification of human knowledge (Barvarz et al., 2014). Beliefs is one of the cognitive component can be based on the scientific evidence, the assumption or intuition (Siegel, 1989). So, epistemological beliefs is individual believe about the source, certainty, and organization of knowledge, as well as the control and the speed of learning (March, 2010). There are several dimensions in beliefs about knowledge, that is the belief that knowledge was uncertain, the belief that knowledge was not fast, the belief that knowledge was complex and the belief that knowledge was vast and infinite (Schommer, 1990).

Study on accounting student relating to personality factors, beliefs about knowledge and towards academic performance is still not much have been done. (Phillips, 1998; Hassal \& Joice, 2001; Davidson, 2002; Ballantine et al., 2008; Fisher 2013). Therefore there is a dire need to do further study to look at the above factors which can contribute to the teachers in their teaching method and also the students will know what type of students they are, and organise where they can improve. 


\section{Theoretical Review}

\subsection{Academic Performance}

Academic performance is the outcome and achievements can be reached by a student in studying in a particular field of study. Academic performance is considered an intellectual competence indicator (Ciorbea \& Pasarica, 2013). Other academic literature on performance is often also referred to as academic achievement. Previous Fan \& Chen (2001) use comprehensive measures covering school GPA, postsecondary attainment, and component test scores in a particular academic area defined academic success among students. The researcher that uses GPA to represent academic performance (Doran \& Smith, 1991; Eckel \& Johnson, 1993;Bonham et al., 2003) found that the GPA is a significant predictor towards academic performance.

\subsection{Personality}

Personality is a variable that is widely used in behavioral studies. According to Graziano (2003), the argument relating to the structure of the personality has been since been on for over 20 years ago. Dimensions of personality that are popular to use in the field of research are known as the big five personality dimensions, namely: (Costa \& McCrae, 1992). Neuroticism is the personality values containing the meaning of stiff, unstable emotions, lack of responsibility and not reliable (Hogan et al., 1994). Neuroticism also includes a set of properties of the confused, depressed, and fragile (Piedmont, 1998). Openness is the personality values containing the meaning of the individual's ability to imagine, broad-minded and all want to know (Hogan et al., 1994). Openness involves a set of properties of a person who likes to imagine, like going to art and beauty, full of feeling, have many ideas (Piedmont, 1998). Agreeableness is personality values containing the meaning of one's sympathy, cooperative, and friendly (Hogan et al, 1994). While according to Piedmont (1998) what is meant by agreeableness is exact nature, likes to come clean, polite and tend to like to think. Conscientiousness is personality values containing the meaning individuals who like to work hard, love to perform duties, controlled (DeNave et al., 1998). Extraversion is personality values containing the meaning of gregarious, assertive, positive emotions; sometimes extraversion may also refer to energetically (Piedmont, 1998). In addition, Extraversion focuses on the quality and intensity of the relationship either (DeNeve et al., 1998).

\subsection{Beliefs about Knowledge}

Schommer (1990) has divided the beliefs of knowledge and learning into four dimensions, namely: Certain (undeniable), this first dimension indicated that naïve students would believe that knowledge was uncertain and undeniable, on the other hand, other students believe about more sophisticated view that knowledge was uncertain and flexible. The second dimension, namely: Simple, this dimension reflected student's beliefs that varied about whether or not knowledge consisted of multiple groups from an easy element integration or fact classification. The third dimension is Could be obtained quickly, it is included naïve students who viewed learning as could be obtained quickly and also other students with more modern, views, who believed that learning needed hard works. The last dimension is Without any Limit: this dimension showed that several students who have a naïve perspectives viewed that knowledge came after talent and, on the other hand, there were more sophisticated views with the belief of knowledge that can be added every time.

The division of these beliefs was called 'epistemological beliefs' in existing psychological literature on social and mathematic sciences students (Schommer \&Walker 1995); whatever the similarity level of belief dimensions of students in the field of applied sciences such as accounting has not been known.

\subsection{Hyphoteses of this study}

1. Personality and Beliefs about knowledge influence the academic performance of accounting students at level university with A accreditation

2. Personality and Beliefs about knowledge influence the academic performance of accounting students at level university with B accreditation

3. Personality and Beliefs about knowledge influence the academic performance of accounting students at level university with $\mathrm{C}$ accreditation

\section{Research Method}

\subsection{Participants}

The participants were 750 accounting students from universities in Indonesia. The university, which is a public and private university is Level A, B and C accreditation, determined by The National Accreditation Institution for the Indonesian University, 2015.

Data for this research was collected through two forms namely: questionnaires and Cumulative Achievement Index. The questionnaires submitted to the respondent are made simple and as clear as possible. 


\subsection{Instrument of the research}

The instrument of Personality developed by John \& Srivastava (1999), also known as The Big Five Traits Taxonomy. Belief about knowledge (Belief Dimensions) are the instruments the questionnaire developed by Schommer (1990,1993). These questionnaire used a likert scale using of five starts from 5 (strongly agree), 4 (agree), 3 (neutral), 2 (disagree) and 1 (strongly disagree)..

\subsection{Data Analysis Techniques}

Data that has been collected is analyzed with the correlation and regression analysis. The results of the analysis will consist of testing the quality of the data, regression analysis and test hypotheses.

\section{Result and discussion}

\subsection{Test Validity and Reliability of the Instrument}

Every item of validity index value is greater than the value of $r$ table, either at $\alpha=5 \%$ or $1 \%$. Thus can be inferred that the whole items for the third variables, i.e.personality factors, beliefs about knowledge are valid and commendable to be used as a instrument tool to measure the variable capacity: personality factors and beliefs about knowledge. Value reliability statement on each itemfor the third variables being researched is greater than 0.60. Reliability measurement is done by using Cronbach Alpha $(\alpha)$. According to Rubera \& Eisingerich (2010), the value of the minimum level of reliability is 0.6 (Cronbach's Alpha).

\subsection{Hypotheses Test}

The hypotheses testing is done by analyzing the value of C. R (Critical Ratio) and the $p$ value and then compared to the required statistical limitations, i.e. above 2.0 to C.R value and less or equal to 0.05 for the $p$ value. When the results of the organized data show the value had qualified, then the hypothesis of the research proposed is acceptable. Further discussion of hypothesis testing will be done gradually in accordance with the sequence of hypotheses have been proposed.

\subsection{The result of Hypotheses 1}

\subsubsection{The Path analysis (A accreditation)}

To analyze the direct relationship of causality between the personality factors and influences (X1), beliefs about knowledge (X2) on the academic performance of accounting students at the university of level accreditation A, a path analysis method is used. The obtained result on the path coefficient analysis testing is show in Table 1.

TABLE I. PATH COEFFICIENT TESTING

\section{Coefficients $^{\mathrm{a}}$}

\begin{tabular}{|ll|l|l|l|}
\hline \multirow{2}{*}{ Model } & \multicolumn{2}{|l|}{ Standardized Coefficients } & & \\
\cline { 2 - 3 } & Beta & T & Sig. \\
\hline $1 \quad$ (Constant) & & 5.650 & .000 \\
X1 (Personality) & .120 & 1.541 & .125 \\
X2 (Beliefs about knowledge) & .226 & 3.262 & .001 \\
\hline
\end{tabular}

a. Dependent Variable: Academic Performance

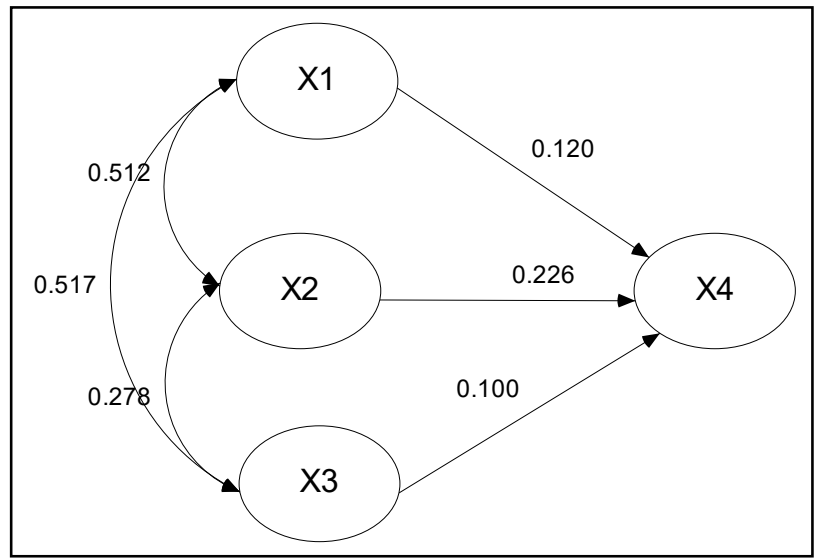

Figure 1 .Path Coefficient

\subsubsection{The Path analysis (B accreditation)}

To analyze the direct relationship of causality between the personality factors and influences (X1) and beliefs 
about knowledge (X2) on the academic performance of accounting students at the university of level accreditation $\mathrm{B}$, a path analysis method is used. The obtained result on the path coefficient analysis testing is show in table 2 .

TABLE II PATH COEFFICIENT TESTING

Coefficients $^{\mathrm{a}}$

\begin{tabular}{|ll|l|l|l|}
\hline \multirow{2}{*}{ Model } & \multicolumn{2}{|l|}{ Standardized Coefficients } & & \\
\cline { 2 - 3 } & Beta & & S \\
\hline $1 \quad$ (Constant) & & 6.412 & .000 \\
X1 (Personality) & .275 & 3.891 & .000 \\
X2(Beliefs about knowledge) & .124 & 1.838 & .067 \\
\hline
\end{tabular}

Dependent Variable:Academic Performance

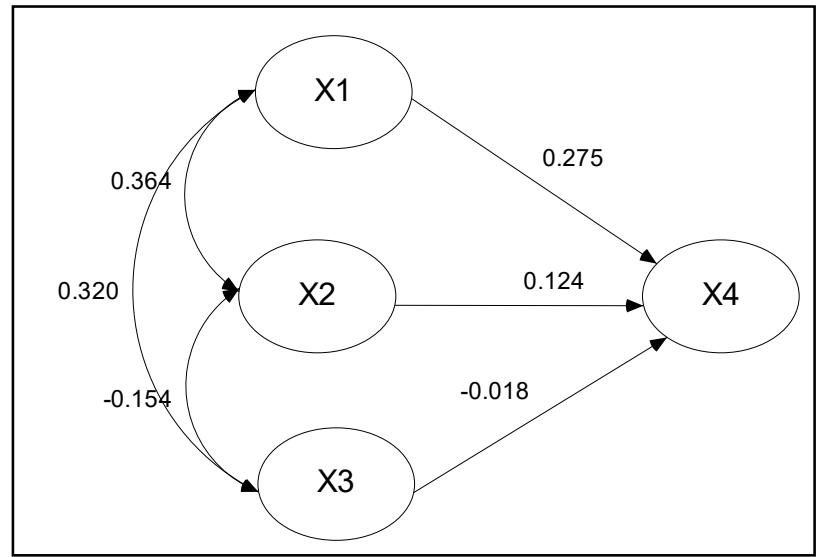

Figure 2 .Path Coefficient

\subsubsection{The Path analysis (C accreditation)}

To analyze the direct relationship of causality between the personality factors and influences (X1) and beliefs about knowledge (X2) on the academic performance of accounting students at the university of level accreditation $\mathrm{C}$, a path analysis method is used. The obtained result on the path coefficient analysis testing is show in table 3 .

TABLE III.
\begin{tabular}{|l|l|l|l|}
\hline Coefficients $^{\text {a }}$ & PATH COEFFICIENT TESTING \\
\hline \multirow{2}{*}{ Model } & Standardized Coefficients & & \\
\cline { 2 - 5 } & Beta & T & Sig. \\
\hline (Constant) & & 5.573 & .000 \\
\hline X1 (Personality) & .284 & 4.177 & .000 \\
\hline & & & \\
X2(Beliefs about knowledge) & .172 & 2.597 & .010 \\
\hline
\end{tabular}




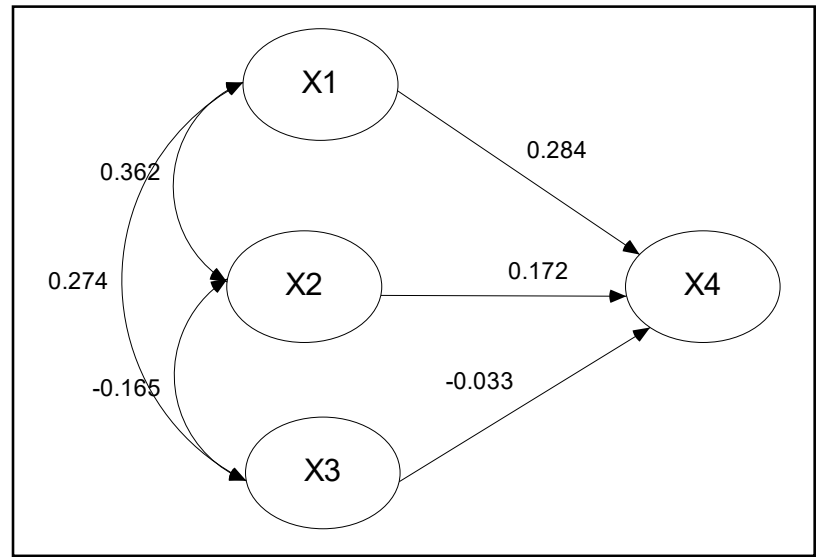

Figure 3 .Path Coefficient

\subsubsection{The coefficient of determination coefficients and path on the 3rd level of accreditation}

Based on testing performed on the third level above, will further facilitate the interpretation regarding the third level accreditation then the displayed line and great influence coefficient in the table as follows:

TABLE IV.

THE COEFFICIENT OF DETERMINATION COEFFICIENTS AND PATH ON THE 3RD LEVEL OF

\begin{tabular}{|l|l|l|l|}
\multicolumn{4}{|c}{ ACCREDITATION } \\
\hline \multirow{2}{*}{ No } & \multirow{2}{*}{ Level } & \multicolumn{2}{|l|}{ Path Coefficient } \\
\cline { 3 - 4 } & & $\rho_{\mathrm{yx} 1 \text { (Personality) }}$ & $\rho_{\mathrm{yx} 2 \text { (Beliefs) }}$ \\
\hline 1 & $\mathrm{~A}$ & 0.120 & 0.226 \\
\hline 2 & $\mathrm{~B}$ & 0.275 & 0.124 \\
\hline 3 & $\mathrm{C}$ & 0.284 & 0.172 \\
\hline
\end{tabular}

Based on the table above it can be concluded that the 4.4 on based on the path coefficients obtained accreditation level $\mathrm{C}$ provides the largest line coefficient on the variable personality, which means the final year student GPA at university of level accreditation $\mathrm{C}$ more influenced by personality when compared to universities with accreditation of A or B. Accreditation level with path coefficient gives the value of the coefficient of the variable path beliefs about knowledge which emphasizes student GPA at the end of the level to the level of University accreditation with more influenced by beliefs about knowledge compared with university accreditation $\mathrm{B}$ or $\mathrm{C}$. While based on the coefficient of determination, with university of level $\mathrm{C}$ provides the greatest influence on others, meaning that a third variable simultaneously will further affect the student's GPA at university of level accreditation $\mathrm{C}$

\section{Summary and Conclusion}

This research aims to test the influence of Personality and Beliefs about Knowledge towards the Academic Performance. Beside that, this research also compared the influence of personality and Beliefs about knowledge towards Academic performance of accounting students at three level university accreditation to know what factors could make the strongest effect. The results showed that there was influence between the Beliefs about knowledge towards Academic performance at A accreditation. There was influence of Personality towards the Academic Performance at $\mathrm{B}$ accrediation. For $\mathrm{C}$ accreditation, there were influence of personality and Beliefs about knowledge at $\mathrm{C}$ accreditation. The result also showed that the final year student GPA at university of level accreditation $\mathrm{C}$ more influenced by personality when compared to universities with accreditation of $\mathrm{A}$ or $\mathrm{B}$. Accreditation level with path coefficient gives the value of the coefficient of the variable path beliefs about knowledge which emphasizes student GPA at the end of the level to the level of University accreditation with more influenced by beliefs about knowledge compared with university accreditation B or C.

For future research is advised to look for another behavior variables that can influence the academic performance, especially in the field of accounting.

\section{References}

[1] Anton, C. (2014). Indonesia Kekurangan Akuntan Profesional. 27 Juni 2014, from http://ekbis.sindonews.com/read/877716/34/indonesia-kekurangan-akuntan-profesional-1403869825.

[2] Barvarz, R., Nami Y., \& Ahmadi, S. (2014). The Relationship between the Epistemological Beliefs and Academic Performance. Social and Behavioral Sciences, 114, 121- 124.

[3] Bonham, S., D. Deardorff., \& R. Beichner.(2003). Comparison of Student Performance Using Web and Paper-Based Homework in College-Level Physics. Journal of Research in Science Teaching, (Vol. 40, No. 10), 1050-1071. 
[4] Cano, F. (2005). Epistemological Beliefs and Approaches to learning: Their change through secondary school and their influence on academic performance. British Journal of Educational Psychology, 75, 203-221.

[5] Chamorro-Premuzic, T., \& Furnham, A. (2008). Personality, intelligence and approaches to learning as predictors of academic performance. Personality and Individual Differences, 44, 1596-1603..

[6] Ciorbea, J., \& Pasarica, F. (2013). The study of the relationship between personality and Academic performance. Procedia : Social and Behavioral Science,78, 400-404.

[7] Costa, P. T., Jr., \& McCrae, R. (1992). Revised NEO Personality Inventory (NEO-PI-R) and NEO Fivefactor Inventory (NEO-FFI): Professional manual. Odessa, FL: Psychological Assessment Resources Inc.

[8] Davidson, R. A.(2002). Relationship of Study Approach and Exam. Performance.Journal of Accounting Education, Ed. 20, 29-44.

[9] DeNeve, K.M., \& Cooper, H. (1998). The Happy Personality : A Meta analysis of 137 personality traits and subjective well-being. Psychological Bulletin, 124, 197- 229.

[10] De Raad, B., \& Schounwenburg, H. C. (1996). Personality traits in learning paradigm ultility in business and management education. Paper presented at the Academy of management conference, Washington, DC,August 2001.

[11] Doran, B. M., Bouillon, M., \& Smith, C. G. (1991). Determinants of student performance in accounting principles I and II. Issues in Accounting Education, 6(1), 74-84.

[12] Duff, A., Boyle., E, Dunleavy, K., \& Ferguson, J. (2004).The Relationship between Personality, Approach to learning and Academic Performance. Personality and Individual Differences, 36, 1907-1 920.

[13] Fan, X., \& Chen, M. (2001). Parental involvement and students' academic achievement: A meta-analysis. Educational Psychology Review, 13(1), 1-22.

[14] Graziano.W.G. (2003). Personality Development:An Introduction toward Process Approaches to Long-term stability and change. Personality and Individual Differences, 71, 893-904.

[15] Gujarati, D.N. (1988). Basic Econometrics.Second Edition.Singapore : MacGraw Hill Book Co.

[16] Hair, J.F., Anderson., Tatham., \& Black (1998).Multivariate Data Analysis. Fifth Edition.USA:Prentice-Hall International,Inc.

[17] Hair, J.F. (2006). Multivariate Data Analysis. Sixth Eddition.New Jersey: Pearson Educational Inc.

[18] Heiskanen, H., \& Lonka, K. (2012). Are epistemological beliefs and motivational strategies related to study engagement in higher education? Social and Behavioral Science, 69, 306-313.

[19] Hogan, R., Curphy, G,J., \& Hogan,J. (1994).What We Know About Leadership : Effectiveness and Personality. American Psychologist, 49, 493-504.

[20] Indonesian Institute of Certified Public Accountant. (2015).Anonim. Bersiap Diri Menyambut Pasar Tunggal ASEAN.<http://www.iaiglobal.or.id/v02/berita/detail.php?catid\&id=617>.

[21] John, O. P., \& Srivastava, S. (1999). The Big-Five trait taxonomy: History, measurement, andtheoretical perspectives. In L. A. Pervin \& O. P. John (Eds.), Handbook of personality: Theory and research (Vol. 2, pp. 102-138). New York: Guilford Press.

[22] Joreskog,K.G., Sorbom., Toit,S.d., \& Toit,M.d. (1999). LISREL 8 : New Statistical Feature. Chicago : Scientific Software International,Inc.

[23] Kusnendi. (2008). Model-model Persamaan Sstruktural : Satu dan Multigrup sampel dengan LISREL.Penerbit : Alfabeta.Bandung.

[24] March, L. M. (2010). Epistemological Beliefs and Approaches to learning: Influence on Academic Performance in Higher Education. A dissertation Submitted in Doctor of Philosophy. Capella University.

[25] Mitrofan, N., \& Ion., A. (2013). Predictors of Academic Performance. The Relation betweenthe Big Five Factors and Academic Performance. Procedia : Social and Behavioral Science,78, 125-129.

[26] Nunnally, J. C. (1978). Psychometric Theory (2nd ed.). New York: McGraw-Hill

[27] O'Connor, M. C., \& Paunonen, S. V. (2007). Big Five personality predictors of post secondary academic performance. Personality \& Individual Differences, 43, 971-990.

[28] Phan, H.P. (2006). Examination of Student learning approaches,reflective thinking, and epistemological beliefs; A latent variables approach. Electronic Journal of Research in EducationalPscyhology.

[29] Phillips, F.(1998). Accounting students'associating beliefs about knowledge : Associating Performance with Underlying Belief Dimensions . Issues in Accounting Education, (Vol. 13, No. 1), 113-126.

[30] Piedmont, R.L. (1998). The revised Neo Personality Inventory Clinical and research applications. New York :Plenum Press.

[31] Poropat, A. (2009). A meta-analysis of the five-factor model of personality and academic performance. Psychological Bulletin, 135(2), 322-338.

[32] Schommer, M. (1990). Effects of beliefs about the nature of knowledge on comprehension.Journal of Educational Psychology, 82, 498-504.

[33] Schommer, M. (1993). Epistemological development and academic performance among secondary students, Journal of Educational Psychology, 85, 406-411. 
[34] Schommer, M., \& Walker, K. (1995). Are epistemological beliefs similar across domains? Journal of Educational Psychology, 87, 424-432.

[35] Siegel, G., \& Helene, R.M. (1989). Behavioral Accounting.South-Western Publishing Co, Cincinnati, Ohio.

[36] Svensson, L. (1977). On a qualitative differences in learning:III Study skill and learning. British Journal of Educational Psychology, 47, 233-243.

[37] Wellyan, R. (2015). Jumlah Akuntan Indonesia Masih Belum Mencukupi Permintaan Domestik. https://duniaakuntan.wordpress.com/2015/...jumlah-akuntan-Indonesia. Retrieved 21/3/16. 